\title{
A variação em semitons na sincronia de interação em entrevistas ${ }^{3}$
}

Mayara de Sousa; Amanda Lassak; Renata Rosa

\section{Introdução}

Nas conversas espontâneas ocorre o fenômeno conhecido como sincronia de interação (KNAPP; HALL, 1999), isto é, a variação conjunta de movimentos durante a troca de informações entre os falantes. Os falantes tendem, de maneira semelhante, a variar conjuntamente aspectos prosódicos de seus turnos conforme os contextos situacionais e emocionais. A observação e comparação dos tons médios dos turnos dos dois falantes em cada conversa revelaram que houve correlação entre a variação de tom e a mudança de turno (SOUSA, 2009). Essa variação para ser perceptivelmente relevante deverá ser, segundo trabalhos anteriores, maior que 3 semitons ascendentes e 4 descendentes (ROSA, 2008; CONSONI; FERREIRA NETTO, 2008; LASSAK, 2009).

\section{Objetivo}

Focalizando o tom médio da fala, este projeto buscou verificar a existência ou não de sincronia de interação em entrevistas, observando os tons que foram utilizados por esses falantes.

\footnotetext{
3 9o CONGRESSO NACIONAL DE INICIAÇÃO CIENTÍFICA DO SEMESP - CONIC. São Paulo, 2009.
} 


\section{Metodologia}

A análise baseou-se no corpus coletado por Sousa (2009), composto por 30 conversas e entrevistas entre duas pessoas 10 conversas entre homens $(\mathrm{H}-\mathrm{H}), 10$ entre mulheres $(\mathrm{M}-\mathrm{M})$ e 10 entre homens e mulheres $(\mathrm{M}-\mathrm{H})$. Os dados foram analisados pela rotina ExProsodia (FERREIRA NETTO, 2008). Foram realizadas análises comparativas entre os tons subsequentes utilizados pelos pares de interlocutores de cada diálogo.

\section{Apresentação e Discussão dos resultados}

A análise dos tons utilizados pelos falantes aponta para o fato de que a variação conjunta de movimentos, levando em conta a premissa dos 3 semitons ascendentes, foi observada em apenas $16 \%$ dos casos. A análise particularizada do grupo $\mathrm{H}-\mathrm{H}$ evidenciou que em $30 \%$ dos casos ocorreu a variação perceptivelmente relevante, no grupo $M-M$ foi de $10 \%$ e no $M-$ H 10\%. Esses resultados corroboram a hipótese de Sousa (2009) no que diz respeito à influência do contexto situacional e emocional dos falantes na interação. Segundo a autora, as conversas entre homens seriam construídas por discussões e debates, na maioria das vezes, sobre temas polêmicos. Na tentativa de acompanhar o tom médio de seu interlocutor, o falante elevaria sua tessitura e faria, assim, com que o interlocutor procurasse um nível ainda mais alto para rebater ou acrescentar seus argumentos. 